\title{
Effect of genetic and non-genetic factors on milk yield and milk constituents of Sahiwal cattle
}

\author{
M.K. VERMA, G.K. SACHDEVA, S. GAUTAM, M.M. ALI, R. KUMAR AND S. BINDAL
}

\begin{abstract}
The present study pertained to records on milk production and milk constituents of 259 Sahiwal cattle with 600 lactations spread over a period of 10 years from 2001 to 2010, collected from Dairy Cattle Breeding division of National Dairy Research Institute, Karnal, Haryana. To study the effect of various genetic and non-genetic factors on milk yield and milk constituents traits, mixed model least square analysis was used for analysis of data. Overall least square mean for all lactation traits of total milk yield (TMY), milk yield in 305 days or less (305MY), lactational average fat per cent (LFA) and lactational average solid not fat per cent (LSA) were $1880.39 \pm 73.82 \mathrm{~kg}, 1782.97 \pm 68.37 \mathrm{~kg}, 4.71 \pm 0.01$ per cent and $8.81 \pm 0.01$ per cent, respectively. Analysis of variance showed that the differences were statistically significant for the effect of sire on TMY and 305MY; period on all the traits except TMY; parity on 305MY. However, the effect of season of calving was not found significant on all the traits.
\end{abstract}

KEY WORDS : Genetic and non-genetic factors, Mixed model, TMY, 305MY, LFA, LSA

How TO CITE THIS PAPER : Verma, M.K., Sachdeva, G.K., Gautam, S., Ali, M.M., Kumar, R. and Bindal, S. (2015). Effect of genetic and non-genetic factors on milk yield and milk constituents of Sahiwal cattle. Res. J. Animal Hus. \& Dairy Sci., 6(1) : 44-47.

S. Gautam, Division of Dairy Cattle Nutrition, National Dairy Research Institute, KARNAL (HARYANA) INDIA

M.M.Ali and S. Bindal, Livestock Production and Management Section, National Dairy Research Institute, KARNAL (HARYANA) INDIA

R. Kumar, Bihar Veterinary College, PATNA (BIHAR) INDIA 